\title{
Pyrethrum as an Insecticide and its Cultivation in England.
}

\section{By J. C. F. Fryer and C. T. Gimingram, Plant Pathological Laboratory, Ministry of Agriculture.}

$\mathrm{T}^{\mathrm{H}}$

insecticidal properties of the flowers of certain species of pyrethrum (Chrysanthemum) have been known for a long period, the very high toxicity of the active principles to insects and their harmlessness to man and warm-blooded animals forming an almost unique combination of qualities. It is, however, within the last decade only that the chief advances towards a detailed knowledge of these plants have been made, and the marked interest aroused in the subject recently makes it appropriate to direct attention to the present position of investigations undertaken in Great Britain.

Three species of pyrethrum, Chrysanthemum cinerariofolium Trev., $C$. coccineum Willd., and $C$. marschalli Ascher (roseum Bieb.), possess insecticidal properties. Of these, the first named is much the most important; its flowers constitute the great bulk of the pyrethrum of commerce, and the work to be referred to has been confined almost exclusively to this species. The plant is a native of the Mediterranean coast region, and is widely cultivated there and in Japan*; it is now also grown commereially for home consumption in Switzerland, France, and North Africa.

Experiments on the cultivation of pyrethrum in England were started in 1925 by the Plant Pathological Laboratory of the Ministry of Agriculture, ${ }^{1}$ small plots being laid down at some sixteen centres on a variety of different types of soil. In co-operation with the Insecticides and Fungicides Department of Rothamsted Experimental Station, samples of the produce from many of these plots during the years 1926-29 were tested by a biological method and later examined chemically (see below), and, without going into details, it may be said that the result of these experiments has demonstrated that pyrethrum can be grown and harvested successfully under English conditions, that the average yield of dried flowers is of the same order as that obtained elsewhere, and that the insecticidal efficiency of the product is not less than that of imported samples. ${ }^{2}$ The plants proved quite hardy and successfully withstood the fairly severe winters of 1927-29; a plot at Harpenden, planted in 1925, is still in good condition and gave its highest yield of flowers in 1930. These experiments, however, were on too small a scale to give data on which an opinion could be formed as to the economic possibilities of growing pyrethrum in England, and arrangements were therefore made to plant up several larger areas of $\frac{x}{2}$ to 1 acre, for which detailed costings could be kept. Four of these bigger plots yielded their first harvest of flowers in 1930, and another should come into bearing this year. It will be necessary to continue these investigations for several years before the desired information is obtained, but the first year's figures are, on the whole, not discouraging, though in one case the grower considered the crop too troublesome and has decided to discontinue the experiment. The produce from all four plots was of high quality ; two gave a yield which is about the average for a first-year crop, the yield from the third was rather below the average, and from the fourth was very much higher. Costs of planting and cultivation are much greater in the first year than later, but reckoning the produce at the current price of imported flowers (at present rather low), expenses were about covered in the case of the fourth plot.

* Japan now provides about 70 per cent of the world's supply of pyrethrum. For details of the history and present position of pyrethrum-growing in Japan and the methods of cultivation adopted, see an article by the British Vice-Consul at Seoul in Bull. Imp. Inst., Oct. 1930 , p. 300 .

No. 3206, Vor. 127]
These plots should continue to crop for at least another four years, during which the expenses of cultivation will be greatly reduced. Thus, although the results so far obtained do not warrant confidence as to ultimate success, they certainly justify the continuation of the experiments. Cutting the flowers by hand is probably the most serious item of expense, and labour costs will be considerably reduced if a mechanical means of harvesting can be devised.

Laboratory investigations have proceeded concurrently with the field experiments. The brilliant investigations of Staudinger and Ruzicka ${ }^{3}$ elucidated the composition of the active principles of pyrethrum and showed that these were two esters of complicated structure, to which the names pyrethrin I. and pyrethrin II. were given. A method for the determination of these substances was also suggested by Staudinger and Harder. ${ }^{4}$ Following up these researches, analytical methods, involving the use of only small amounts of material, were worked out at Rothamsted, and a number of samples were examined both biologically and chemically. A close correla. tion was found between the percentage of pyrethrins in a series of samples and the observed insecticidal efficiency under standard conditions. ${ }^{5}$

Another point to which special attention has been given is the relationship between the stage of development of the flower and the pyrethrin content. It is an established convention in the trade that pyrethrum flowers picked before they are fully open ('half opened') possess greater insecticidal value than the fully opened flowers, and higher prices are given for the former. $\dagger$ Biological experiments carried out under standard conditions have, however, shown that the toxicities of extracts of equal weights of pyrethrum flowers at different stages of development do not differ significantly, ${ }^{2}$ and a detailed investigation by Dr. F. Tattersfield (not yet published) of the pyrethrin content of flowers taken week by week over the flowering period, in which the large mass of data obtained is dealt with statistically, shows that the percentage of pyrethrins present increases up to the stage at which the flowers are fully open. Gnadinger and Corl, ${ }^{6}$ in America, using a different analytical method, have also found that the pyrethrin content of the flowers increases with maturity. The point is of great practical importance, since the yield both of flowers and of active principles which can be harvested per unit area increases markedly with increasing maturity of the flowers.

Evidence has accumulated in the past two years that many samples of pyrethrum grown in England contain a higher percentage of pyrethrins than is generally found in imported consignments. Figures of 1.5-2.0 per cent are not uncommon, whereas imported samples commonly contain not more than 0.5 per cent. Further, analysis of the flowers of individual plants have shown wide variations in pyrethrin content, and the possibility of evolving improved strains is under consideration.

Pyrethrum insecticides were formerly confined very largely to powders obtained by grinding the dried flowers, but in recent years preparations for use as horticultural spray fluids have been on the market in America, and kerosene extracts of the flowers have been widely sold as fly sprays. As was pointed out by Staudinger and Ruzicka, the pyrethrins undergo hydrolysis with alkalis, and

† This opinion had been challenged by Swiss, French, and American workers many years ago, but without affecting the custom of the trade. 
preparations containing soap, such as the French 'savon pyrèthre', are liable to gradual deterioration; petroleum extracts with a non-alkaline emulsifier are, however, stable for considerable periods. A formula for the preparation of a spray fluid of the latter type has been published by Tutin, ${ }^{7}$ and proprietary products of a similar kind were placed on the English market last year.

Walton ${ }^{8}$ has obtained very promising results with sprays of this type for the control of the raspberry beetle, a serious pest of raspberries and loganberries; and preliminary experiments with these fluids against red spider and against the apple capsid bug, both important pests of fruit and difficult to control, have also been successful. Although different kinds of insects vary somewhat in the degree of resistance that they offer to the effects of pyrethrum, a great many important pests are killed by preparations containing 0.0025 to 0.005 per cent of pyrethrins, that is, approximately the equivalent of 0.5 to 1.0 per cent of flowers. The pyrethrins appear to act upon insects as nerve poisons, and they are undoubtedly among the most powerful insecticides known; the range of their usefulness has by no means yet been fully explored.

1 J. C. F. Fryer and R. Stenton, Min. Agric., 33, 916; 1927.

2 J. C. F. Fryer, F. Tattersfield, and C. T. Gimingham, Ann. App Biol., 15, 423; 1928 .

${ }^{3}$ Helv. Chim. Act., 7, 177; 1924

Ann. Acad. Sci. Fennicoe, A, 29, No. 18; 1927

5 (a) F. Tattersfield, R. P. Hobson, and C. T. Gimingham, J. Agric. Sci., 19, $266 ; 1929$.

(b) F. Tattersfield and R. P. Hobson, J. Agric. Sci., 19, 434; 1929 (c) J. T. Martin and F. Tattersfield, J. Agric. Sci. 21, 115; 1931 - J. Amer. Chem. Soc., 51, 3054; 1929 : 52, 680 ; 1930.

F. Tutin, Long Ashton Res. Stat. Rept., p. 96; 1928: p. $93 ; 1929$ - C. L. Walton, J. Pom. and Hortic. Sci., 8, 173, $309 ; 1930$.

\section{Geology in Great Britain.}

THE "Summary of Progress" of the Geological Survey of Great Britain for 1929 is issued in three parts, of which the first is devoted to an account of the routine work during the year under review, while the others contain papers on subjects of special interest. Part $\mathrm{I}^{1}$ embodies the annual reports of the Geological Survey Board and of the Director. Sixtysix maps were published during 1929, with eight memoirs, which, with the exception of that dealing with Moreton in Marsh (see below), have already been noticed in our columns (NATURE, Aug. 16, 1930, p. 258). The memoirs in the press at the close of the year have since appeared and are reviewed below.

The most important event in the progress of the Survey during 1929 was the beginning of operations for the building of a new museum, library, and offices on a site in Exhibition Road, South Kensington, midway between the Natural History Museum and the Science Museum. The Geological Museum will have direct connexion with each of these by means of passages open to the public. The work now in progress will take at least three years to complete. New offices have been occupied in Edinburgh and a scheme for the erection of an additional building is under consideration. Field work has for some years been concentrated on the revision of the coalfields. In Yorkshire, Lancashire, and Northumberland this is still actively in progress; elsewhere the surveys are approaching completion, though the maps and memoirs have still to be published. Reports on six districts in England and four in Scotland, and on the palæontological, petrological, and chemical work in progress, contain many records of current interest.

In Part $2^{2}$ the results of a magnetic survey of part of north Leicestershire are recorded and discussed by A. F. Hallimond. A valuable petrological study of the hornfelses from Kenidjack, Cornwall, is provided by C. E. Tilley and Sir John Flett. It is thought that the original dolerite intrusions of the area were intensely weathered and leached, and afterwards sheared and thermally metamorphosed with the production of cordierite-anthophyllite rocks and cummingtonite rocks. In view of the occurrence of similar rocks elsewhere in puzzling circumstances, this paper is of much more than local importance. H. G. Dines and F. H. Edmunds show conclusively that it is unsafe to base stratigraphical deductions on mechanical analyses of the formations of the Lower Greensand. Four other papers record noteworthy stratigraphical and palæontological observations.

Part $3^{3}$ contains an account of magnetic work on the Swynnerton Dyke, also by A. F. Hallimond. Sir John Flett describes a teschenite, 224 feet thick, encountered in a boring at Easter Dalmeny, west of
Edinburgh, and devotes special attention to the variation of mineral composition and specific gravity with depth. The discussion of differentiation is particularly illuminating and should be seen by all petrologists. Bernard Smith contributes a useful study of the origin of the St. Bees-Whitehaven Gap. Important palæontological investigations are recorded in R. Crookall's account of Paloeoxyris and related genera, and in W. S. Bisat's paper on the goniatite and nautiloid fauna of the Middle Coal Measures of England and Wales. The accurate determination of hitherto confused species makes possible a notable advance in the correlation of the English and German Coal Measures. Other papers deal with the Pliocene of Hertfordshire and a boring in the Lower Oil-shale Group of Burntisland.

Few memoirs in recent years have approached that dealing with north Ayrshire, ${ }^{4}$ in the wide variety, general interest, and scientific importance of the topics discussed. The area is characteristic of much of the Central Valley of Scotland, and includes a long succession of sediments from the Downtonian to the New Red Sandstone, and a remarkable number of igneous episodes of different ages. Lava suites occur in the Lower Old Red Sandstone, Calciferous Sandstone, Millstone Grit, and New Red Sandstone (? Permian). In addition, beds of volcanic ash occur at intervals in the Limestone Coal and Upper Limestone Groups, and there are many north-west dykes that can confidently be referred to the Tertiary. A remarkable range of petrographic types is represented, and petrologists abroad, as well as at home, will find the memoir a rich storehouse of highly significant records, analyses, and associations. A summary of the geology and an account of previous researches are given in the first two chapters. The chief rock groups, sedimentary and igneous, are ably dealt with in successive chapters. Special attention is directed to the fauna of the Carboniferous and the flora of the Coal Measures. A detailed account of the glaciation of the district follows and includes a description of fossiliferous beds of Pleistocene age found beneath the boulder clay of certain areas. A special feature of the memoir is the chapter on the soils and agriculture of north Ayrshire. It should be noted that in addition to the beautiful one-inch maps (Solid and Drift editions) published in 1928 , a soil-texture map on the same scale is also available. The latter was issued in 1929 and was prepared under the supervision of the late Prof. R. A. Berry.

The new memoir on the Alnwick district ${ }^{5}$ deals with the country stretching from the Cheviot foothills to the coast between Warkworth and Embleton, and includes some of the chief beauty-spots of North- 